\title{
Financial Integration in the Pacific Basin Region: RIP by PANIC Attack?
}

\author{
Somchai Amornthum* \\ Department of Economics \\ University of Hawai'i at Manoa \\ \& University of Hawai'i Economic Research Organization \\ and \\ Carl Bonham* \\ Department of Economics \\ University of Hawai'i at Manoa \\ \& University of Hawai'i Economic Research Organization
}

May 26, 2008

\begin{abstract}
We exploit advances in panel data econometrics to test whether real interest parity holds in the Pacific Basin region. We test for a unit root in the difference between either the US, Japanese or Euro area real interest rate and the real interest rates from a panel of eleven Pacific Basin economies. Unlike extant studies which test for RIP using panel data, we use Bai and Ng's (2004) PANIC test which allows for a very general model of cross-section dependence, including the possibility of cross-unit cointegration. Ignoring the possibility of cross-unit cointegration can lead to severe size distortions and to an over-rejection of the null hypothesis of a unit root. We overturn earlier findings based on first generation panel tests, and demonstrate that cross-unit cointegration lead to incorrect conclusions. We find that RIP holds in the Pacific region. Real interest rates converge to the US rate. We find no support for the hypothesis that Pacific Basin real interest rates converge to either the Japanese or Euro area rates.
\end{abstract}

Keywords: Real Interest Parity, Pacific-Basin Capital Market Integration, Panel Unit Root, PANIC.

JEL codes: F21; F36; C23

\footnotetext{
* Somchai Amornthum is Assistant Economic Specialist at the University of Hawaii Economic Research Organization (UHERO), Department of Economics, University of Hawai i at Manoa. Carl Bonham is Associate Professor of Economics and UHERO Director. Contact Dr. Amornthum at amornthu@hawaii.edu or Dr. Bonham at bonham@hawaii.edu
} 


\section{Introduction}

The process of financial liberalization and integration in the Pacific Basin region began more than 30 years ago when Hong Kong, Malaysia and Singapore lifted their interest rate controls in the mid-1970s. Japan started its gradual process of financial liberalization with interest rate deregulation in 1979, followed by the Philippines, Australia, New Zealand and Indonesia in the early-1980s, and Korea, Taiwan and Thailand in the late-1980s (see for example de Brouwer, 2002). Even following the 1997 Asian financial crisis, efforts to further the financial integration of Pacific Basin economies continue. The restructuring of domestic financial institutions, proposals for an Asian bond market and the Chiang Mai initiatives are just a few examples (Das, 2005, Chap. 7).

It is widely accepted that financial markets in the Pacific Basin region are well integrated with the world financial system, resulting in a convergence of nominal interest rates across the region. Cowen et al. (2006) provide recent evidence that uncovered interest parity (UIP) holds among Pacific Basin economies. In addition, the high volume of trade between Pacific basin economies and Japan may lead prices in this region to converge to Japan's prices, i.e. purchasing power parity (PPP) may hold between Japan and Pacific Basin countries. ${ }^{1}$ These two parity conditions - UIP and PPP - imply that real interest rates will also be equal across countries. Real interest parity (RIP) is often viewed as an indicator of both macroeconomic/financial market integration and the inability of monetary authorities to exploit the real interest rate channel for the conduct of

\footnotetext{
${ }^{1}$ Recent evidence of a yen-dominated Asian exchange rate system is provided by Aggarwal and Mougoue (1996), Tse and Ng (1997), Baharumshah and Ariff (1997), and Azali et al. (2001). Aggarwal et al. (2000) demonstrate that the convergence of prices is weakened when currencies other than the yen are used as numeraire. See Baharumshah and Keat (2005) and references therein.
} 
activist monetary policy. If real interest rates among Pacific Basin economies converge to either the US or Japanese real interest rate, there is a limited role for independent national monetary policies. While there appears to be a growing consensus that Pacific Basin financial markets and goods market are well integrated, there is less consensus on the equality of real interest rates across countries, and there is still some question as to which economy is the most influential in the region. Early studies such as Glick (1987), Glick and Hutchison (1990) and Chinn and Frankel (1995) found little support for RIP in the Pacific region when U.S. real interest rates were used as the base rate. Yet, when Phylaktis (1999) divided the sample into pre- and post-liberalization periods, she found evidence supporting RIP in the latter period. Recently, Baharumshah, Haw, and Fountas (2005) found that Asian real interest rate differentials vis-à-vis Japan are mean reverting, leading them to conclude that real interest parity holds in all Asian countries.

The purpose of this paper is to exploit advances in panel data econometrics to test whether real interest parity holds in the Pacific Basin region and to determine which economy, the US or Japan, exerts the greatest influence in the region. To test for convergence of real interest rates, we follow Wu and Chen (1998); Holmes (2002); Baharumshah et al. (2005); Singh and Banerjee (2006); and Ferreira and Leon-Ledesma (2007) and test for a unit root in the difference between either the US or Japanese real interest rate and the real interest rates from eleven Pacific Basin economies. Unlike earlier work, we use panel unit root tests that allow for cointegration among cross-section units. Ignoring the possibility of cross-unit cointegration can lead to severe size distortions resulting in an over-rejection of the null hypothesis of a unit root (i.e., over-support of RIP). Early 
studies that used panel methods based on the assumption of no cross-unit cointegration or even cross-sectional independence should be interpreted with caution (Banerjee, Marcellino, and Osbat, 2005).

We use Bai and Ng's (2004) Panel Analysis of Nonstationarity in Idiosyncratic and Common components (PANIC). Like other panel unit root tests, PANIC is more powerful than its univariate (i.e., country-specific) counterpart. Unlike second generation tests due to Pesaran (2007) or Moon and Perron (2004), PANIC allows for a more general model of cross-sectional dependence, including the possibility that cross-sectional units are cointegrated. PANIC is particularly well suited to studying RIP as cross-unit cointegration seems particularly likely when studying hypotheses such as PPP, UIP or RIP.

We find that RIP holds in the Pacific region. Real interest rates do converge, and they converge to the US rate. In contrast to Baharumshah et al. (2005), we find no support for the hypothesis that Pacific Basin real interest rates converge to the Japanese rate. We reject the convergence of Pacific region real rates to the Japanese rate even at the $10 \%$ significance level. Also, we find no support for the hypothesis that real interest rates in the Pacific region converge to the Euro Area rate.

The remainder of the paper is organized as follows. Section 2 provides a discussion of RIP and a review of the literature. We explain the PANIC method in Section 3 and discuss the data in Section 4. The results are shown in Section 5. Section 6 concludes. 


\section{$2 \quad$ Real Interest Rate Parity}

The hypothesis that domestic and foreign ex-ante real interest rates are equal may be derived from two classical parity conditions - uncovered interest parity and exante relative purchasing power parity. Uncovered interest parity (UIP) is an equilibrium condition between expected nominal returns on domestic and foreign assets. Assets of similar risk are assumed to be perfect substitutes, and therefore their expected nominal returns are equal in equilibrium,

$$
i_{t}=i_{t}^{*}+E\left[s_{t+k}-s_{t} \mid \Omega_{t}\right]
$$

where $i_{t}$ is the nominal yield on a $k$-period domestic bond issued at time $t$, and an asterisk indicates the foreign-country counterpart to domestic variables. The time $t$ domestic currency price of a unit of foreign exchange (in logs) is denoted $s_{t}$, and $E\left[x_{t+k} \mid \Omega_{t}\right]$ is the mathematical expectation of $x_{t+k}$ conditional on the information set, $\Omega_{t}$, available at time $t$. The ex-ante relative purchasing power parity (EARPPP) condition is implied by relative $\mathrm{PPP}$ - the rate at which the relative price of two currencies change will equal the difference between the domestic and foreign inflation rates (see Roll, 1979; Cumby and Obstfeld, 1984).

$$
E\left[s_{t+k}-s_{t} \mid \Omega_{t}\right]=E\left[\pi_{t+k}-\pi_{t+k}^{*} \mid \Omega_{t}\right] \quad \quad(\mathrm{EARPPP})
$$


The rate of change in the domestic price level from $t$ to $t+k$ is denoted $\pi_{t+k}=p_{t+k}-p_{t}$, where $p_{t}$ is the log of the domestic price level at time $t$.

To derive the real interest parity (RIP) condition, define the ex-ante real interest rate as the difference between the nominal interest rate and the expected rate of inflation, $E\left[r_{t} \mid \Omega_{t}\right] \equiv i_{t}-E\left[\pi_{t+k} \mid \Omega_{t}\right]$, and add equations (2) and (1),

$$
E\left[r_{t} \mid \Omega_{t}\right]=E\left[r_{t}^{*} \mid \Omega_{t}\right] . \quad(\mathrm{RIP})
$$

Assuming rational expectations, the ex-post real interest rate, $r_{t}$, is a noisy proxy for the ex-ante real rate, $r_{t}=E\left[r_{t} \mid \Omega_{t}\right]-\eta_{t}$, where $\eta_{t}=\pi_{t+k}-E\left[\pi_{t+k} \mid \Omega_{t}\right]$ is the rational expectations inflation forecast error. We can rewrite (3) as,

$$
r_{t}=r_{t}^{*}+\varepsilon_{t},
$$

where $\varepsilon_{t}=\eta_{t}^{*}-\eta_{t}$ is a compound error with $E\left[\varepsilon_{t}\right]=E\left[\varepsilon_{t} \mid \Omega_{t}\right]=0$. The ex-post RIP condition in equation (4) implies that, on average, real interest rates in the domestic and foreign economies are equal.

Because real interest rates are often found to be nonstationary, RIP is generally tested using some form of test for a long-run equilibrium relationship between real interest rate pairs. ${ }^{2}$ One approach begins by testing for cointegration between real interest rates

\footnotetext{
${ }^{2}$ Chinn and Frankel (1995) provide evidence that Asian real interest rates are $I(1)$. See a recent survey on the Fisher hypothesis by Cooray (2003).
} 
in two different countries. The hypothesized cointegrating relationship is,

$$
r_{i, t}=\alpha_{i}+\beta_{i} r_{t}^{*}+\varepsilon_{i, t},
$$

where $r_{i, t}$ is the $k$-period ex-post real interest rate in country $i$, and $r_{t}^{*}$ is the corresponding real interest rate in the base country. The strong form of RIP requires cointegration between $r_{i, t}$ and $r_{t}^{*}$ as well as $\alpha_{i}=0$ and $\beta_{i}=1$ (Wu and Fountas, 2000; Holmes, 2002). A weak form of RIP requires cointegration but does not restrict $\alpha_{i}=0$ or $\beta_{i}=1$. Early studies such as Cumby and Obstfeld (1984) estimated an equation similar to (5) using two-step two-stage least squares and rejected the strong form of RIP among industrialized countries. ${ }^{3}$ Other studies using cointegration methods, such as Goodwin and Grennes (1994), found support only for the weak form of RIP. However, when structural breaks were taken into account, Fountas and Wu (1999) concluded that RIP held among European countries during the 1979-1993 period.

For the Pacific Basin region, Chinn and Frankel (1995) reported strong evidence of cointegration between US and Pacific Basin real interest rates but widespread rejection of the hypothesis that $\beta_{i}=1$. They conclude that "RIP appears to be a rare phenomena" (p. 810). Phylaktis (1999) argued that finding cointegration and a reasonable speed of adjustment towards equilibrium is sufficient evidence to conclude that RIP holds. Based on bivariate models such as (5), and treating Japan as the base market, Phylaktis

\footnotetext{
${ }^{3}$ Mishkin (1984), Cumby and Mishkin (1986) and Jorion (1996) estimated a variant of (5); that is, $r_{i, t}-r_{t}^{*}=\gamma_{i} X_{t}+\epsilon_{i, t}$ where $X_{t}$ is any variable known at time $t$. Yet this is not a test of RIP, because $\gamma=0$ can hold regardless of whether $r_{i, t}-r_{t}^{*} \sim I(0)$. Rather, it is a test of the "joint" efficiency of inflation expectations; i.e., that both inflation forecast errors in the domestic and base countries are orthogonal to information known at the time of the forecast (see Pesaran, 1987).
} 
found a single cointegrating relationship for every Pacific Basin real interest rate in her post-liberalization sample period (1981:1-1993:10). In addition, Phylaktis tested for cointegration in trivariate regressions with both the US and Japanese real rates as regressands and found two cointegrating vectors in all country-specific regressions with the exception of Korea. Phylaktis concluded that her results support RIP and capital market integration. Yamada (2002) tested RIP between the US and Japan, and between the UK and Japan. He tested for cointegration in a trivariate VAR using monthly data from 1981 to 1998. He concluded that there exist two cointegrating relationships, and tested the restriction that $\beta_{i}=1$ in each cointegrating vector, treating Japan as the base country. That is, he performed a joint test of the null hypothesis that RIP holds between Japan and the US and between Japan and the UK. He found widespread rejection of the parameter restrictions implied by RIP.

The second approach to testing RIP focuses directly on the real interest rate differential,

$$
D_{i, t} \equiv r_{i, t}-r_{t}^{*}
$$

If real interest rates are non-stationary, they may differ in the short run, but RIP implies a long run equilibrium so that the real interest differential, $D_{i, t}$, must be stationary. ${ }^{4}$ Early studies tested for unit roots in real interest differentials, $D_{i, t}$, using Dickey-Fuller (Dickey and Fuller, 1979) or augmented Dickey-Fuller tests and found little evidence to

\footnotetext{
${ }^{4}$ Given the uniqueness of the cointegrating vector in bivariate relationships, rejecting the null hypothesis of a unit root in $D_{i, t}$, for all $i$, implies that, in equation (5), $\varepsilon_{i, t} \sim I(0)$ and $\beta_{i}=1$ for all $i$. That is, testing for a unit root in $D_{i, t}$ amounts to a test of the null of no-cointegration using a known cointegrating parameter, $\beta_{i}=1$.
} 
support RIP (Meese and Rogoff, 1988; Edison and Pauls, 1993; MacDonald and Nagayasu, 2000). The literature which tests RIP by testing the null of a unit root in real interest differentials is faced with the well-known problem that such tests suffer from both low power and often severe size distortions. These problems are particularly acute in the small samples available for most macroeconomic analysis, even more so when studying newly developed markets such as the economies of the Pacific Rim. The literature has dealt with these small-sample issues by seeking much longer sample periods (Obstfeld and Taylor, 2002; Sekioua, 2008), making use of improved univariate unit root tests (Obstfeld and Taylor, 2002; Ferreira and Leon-Ledesma, 2007), and the use of panel tests to pool information in the cross-section dimension.

Recent developments in the literature on panel unit root tests have led to a growing number of studies adopting this approach. Wu and Chen (1998) tested RIP for nine OCED countries with the US as the base country. They tested the null hypothesis of a unit root in the panel of real interest differentials using tests due to Levin and Lin (1993, hereafter LL), Im, Pesaran, and Shin (2003, hereafater IPS), and Maddala and Wu (1999, hereafter MW). They rejected the null of a unit root and concluded that RIP holds among their sample of OECD countries. Holmes (2002) focused on European real interest rates treating Germany as the base country. Using the IPS test, he found evidence that real interest differentials are stationary over most sample periods. Baharumshah et al. (2005) used the IPS test to study RIP for a panel of ten East Asian countries, with Japan treated as the base country. They rejected the hypothesis that real interest differentials are nonstationary, and concluded that "RIP holds strongly between Japan and Asian 
emerging markets" (p. 81). In contrast, Singh and Banerjee (2006) study real interest rate convergence among emerging markets throughout Asia, Latin America, Eastern Europe, and the Middle East. Using Pesaran's (2007) CADF test, they can not reject the null hypothesis of a unit root in real interest rate differentials.

\section{Econometric Methodology}

The literature on panel unit root tests has grown rapidly in recent years. ${ }^{5}$ While the first generation of panel tests such as LL, IPS, and MW allow for heterogeneity in deterministic components and in the structure of error serial correlation, they all maintain the restrictive assumption of cross-sectional independence. Yet, Banerjee et al. (2005) show that in the presence of cross-unit correlation or cross-unit cointegration, the LL and IPS panel tests suffer from increased size. As a result, studies which use these firstgeneration tests may over-reject the null hypothesis that real interest differentials are stationary; i.e., they may be overly supportive of the RIP hypothesis.

The second generation of panel unit root tests such as Pesaran's (2007) crosssectionally augmented ADF or IPS tests (CADF, CIPS) and the Moon and Perron (2004) test (hereafter MP) explicitly model cross-unit correlation using a common factor structure. Both Pesaran and Moon and Perron assume that the error in the panel unit root regression has an unobserved common factor structure. Pesaran models the error using a single unobserved common factor plus idiosyncratic terms, while Moon and Perron assume that the panel error has multiple unobserved common factors plus idiosyncratic

\footnotetext{
${ }^{5}$ See a recent survey on panel unit root tests by Breitung and Pesaran (2008).
} 
terms. In both cases, the common factor (capturing the effect of cross-unit correlation) is removed before testing for unit roots in the factor-free data. ${ }^{6}$ But, the common factor(s) may be the source of nonstationarity. If the cross-sectional units are cointegrated because they share a common stochastic trend, the CADF/CIPS and MP tests can be seriously oversized. In fact, if the common factor is the only source of nonstationarity, Monte Carlo results from Gengenbach et al. (2005) show that empirical size of the CADF/IPS and MP tests approach 1 as $T \rightarrow \infty$.

To test the null hypothesis of a unit root in $D_{i, t} \equiv r_{i, t}-r_{t}^{*}$, we use Bai and Ng's (2004) Panel Analysis of Nonstationarity in Idiosyncratic and Common components (PANIC). PANIC decomposes $D_{i, t}$ for $i=1, \ldots, N$ and $t=1, \ldots, T$ into common and idiosyncratic components. The main advantage of PANIC is that it allows the common components to be nonstationary; i.e., it allows for cross-unit cointegration. While CADF/CIPS and MP tests perform reasonably well when unit roots are confined to the idiosyncratic terms, Gengenbach et al. (2005) present Monte Carlo evidence demonstrating that only PANIC can detect a unit root caused by nonstationary common factor.

Consider the factor analytic model for the real interest differential, $D_{i, t}$.

$$
D_{i, t}=\alpha_{i}+\lambda_{i}^{\prime} F_{t}+E_{i, t}, \quad i=1, \ldots, N ; \quad t=1, \ldots, T .
$$

where $F_{t}$ is an $r \times 1$ vector of common factors, and $\lambda_{i}$ is an $r \times 1$ vector of factor loadings. The term $\lambda_{i}^{\prime} F_{t}$ is the common component, while $E_{i, t}$ are the idiosyncratic components.

\footnotetext{
${ }^{6}$ Pesaran (2007) uses cross-sectional means to approximate the single common factor, while Moon and Perron (2004) filter out the common factor(s) through transformations.
} 
All real interest rate differentials share the same $r$ common factors $F_{t}$, but the influence of $F_{t}$ may differ across units due to different factor loadings, $\lambda_{i}$. The unit-specific constant $\alpha_{i}$ is included to capture the potential constant wedge between $r_{i, t}$ and $r_{t}^{*}$. The series $D_{i, t}$ is stationary if and only if both the common factor(s) $F_{t}$ and the idiosyncratic errors $E_{i, t}$ are stationary. Because $F_{t}$ and $\lambda_{i}$ can be consistently estimated only for $E_{i, t} \sim I(0)$, Bai and Ng (2004) apply PANIC to the first differenced model,

$$
d_{i, t}=\lambda_{i}^{\prime} f_{t}+e_{i, t}
$$

where $d_{i, t}=\Delta D_{i, t}, f_{t}=\Delta F_{t}$ and $e_{i, t}=\Delta E_{i, t}$ for $i=1, \ldots, N$ and $t=2, \ldots, T$. We follow the common procedure of normalizing $d_{i, t}$ for each cross-section unit to have a unit variance (see for example de Brouwer, 2002). Let $f_{t}^{r}$ and $\lambda_{i}^{r}$ be the estimates of $f_{t}$ and $\lambda_{i}$ when there are $r$ common factors. Also, let $\lambda^{r}=\left(\lambda_{1}^{r}, \ldots, \lambda_{N}^{r}\right)^{\prime}$ and $f^{r}=\left(f_{2}^{r}, \ldots, f_{T}^{r}\right)^{\prime}$. Then, $\lambda_{i}^{r}$ and $f_{t}^{r}$ are the solutions to the optimization problem

$$
V(r)=\min _{\lambda^{r}, f^{r}} \frac{1}{N T} \sum_{i=1}^{N} \sum_{t=2}^{T}\left(d_{i, t}-\lambda_{i}^{r} f_{t}^{r}\right)^{2}
$$

subject to the normalization $\lambda^{r \prime} \lambda^{r} / N=I_{r} \cdot{ }^{7}$ In practice, $\lambda^{r}$ is given by $\sqrt{N}$ times the eigenvectors corresponding to the $r$ largest eigenvalues of $X^{\prime} X$ where $X$ is the matrix of $d_{i, t}$. The estimated common factor (in first differences) is given by $f^{r}=X \lambda^{r} / N$.

We use the method of unobserved components to estimate the common and id-

\footnotetext{
${ }^{7}$ We choose this normalization because it is computationally less demanding when $T>N$ than the alternative $f^{r \prime} f^{r} /(T-1)=I_{r}$ (Bai and Ng, 2002, p. 198).
} 
iosyncratic factors for $q=0, \ldots, 4$ common factors. A consistent estimate of the number of common factors, $\widehat{r}$, is chosen by minimizing the $I C_{p 2}$ information criterion proposed by Bai and $\mathrm{Ng}(2002)$.

$$
I C_{p 2}(q)=\ln \left(V\left(q \mid \lambda^{q}, f^{q}\right)\right)+q\left(\frac{N+T}{N T}\right) \ln C_{N T}^{2}
$$

where $C_{N T}=\min (\sqrt{N}, \sqrt{T})$. The first term on the right hand side of (10) is the log of objective function, while the last term is the penalty associated with overfitting. The estimated number of factors is $\widehat{r}=\arg \min _{0 \leq q \leq 4} I C_{p 2}(q)$, and the estimated common factors and idiosyncratic components are $\widehat{F}_{t}=\sum_{s=2}^{t} f_{s}^{\widehat{r}}$ and $\widehat{E}_{i, t}=\sum_{s=2}^{t} e_{i, s}^{\widehat{r}}$ where $e_{i, t}^{\widehat{r}}=$ $d_{i, t}-\lambda_{i}^{\widehat{r} \prime} f_{t}^{\widehat{r}}$ for $t=2, \ldots, T$.

Once the unobserved components are estimated, we test for a unit root in each common factor and each idiosyncratic component separately using the DF-GLS (Elliott, Rothenberg, and Stock, 1996) test. ${ }^{8}$ The lag length for each unit root test is chosen using the modified Akaike Information Criterion (Ng and Perron, 2001) with a maximum lag of 4. Bai and $\mathrm{Ng}$ prove that unit root tests on the common and idiosyncratic component(s) are asymptotically independent, and their Monte Carlo results indicate that testing for unit roots in each component separately produces tests with better size properties than when conducting a single test on $D_{i, t}$. Intuitively, if one component is stationary and the other is not, the first- and second-generation panel unit root tests may have a hard time identify the nonstationarity of $D_{i, t}$, especially when the stationary component is

\footnotetext{
${ }^{8}$ While Bai and Ng (2004) suggest using the ADF test, Gutierrez (2006) finds that the DF-GLS test has better power than the ADF test.
} 
relatively large.

In addition to testing for a unit root in the individual-country idiosyncratic components, $\widehat{E}_{i, t}$ one at a time, we also use a panel version of the Modified Sargan-Bhargava test (hereafter PMSB) suggested by Bai and Ng (2007). The test is based on the pooled model,

$$
\widehat{E}_{i, t}=\rho \widehat{E}_{i, t-1}+u_{i, t}, \quad i=1, \ldots, N ; \quad t=1, \ldots, T
$$

The null hypothesis is $H_{0}: \rho=1$ against the alternative of $H_{a}: \rho<1$. The PMSB statistic is given by

$$
P M S B=\frac{\frac{1}{N} \sum_{i=1}^{N} M S B_{i}-\mu}{\sqrt{\sigma^{2} / N}},
$$

where $M S B_{i}=T^{-2}\left(\sum_{i=1}^{T} u_{i, t}^{2}\right) / \omega_{u_{i, t}}^{2}$ is the modified Sargan-Bhargava (MSB) statistic proposed by Stock (1999), $\omega_{u_{i, t}}^{2}$ is the Newey-West variance of $u_{i, t}$ calculated with truncation lags set at $4, \mu=1 / 2$ and $\sigma^{2}=1 / 3 .{ }^{9}$ As $N, T \rightarrow \infty$, the PMSB statistic converges in distribution to the standard normal distribution. ${ }^{10}$

\section{Data}

To test for RIP we study eleven Pacific Basin economies including Canada, Hong Kong, South Korea, Singapore, Taiwan, Indonesia, Malaysia, the Philippines, Thailand, Australia and New Zealand. We test for convergence of real interest rates in these markets to three base rates - the US, Japanese and Euro rates. Previous studies have only focused

\footnotetext{
${ }^{9}$ This representation of PMSB follows Bai and Carrion-i-Silvestre (2005).

${ }^{10}$ Bai and Ng suggest three tests - the $P_{a}, P_{b}$ and PMSB tests - as well as modifications to the MP test. Only the PMSB test does not require the cross-sectional independence of $\widehat{E}_{i, t}$. Monte Carlo experiments reported by Bai and Ng also show that the PMSB test has better size properties than other tests when $N$ is small.
} 
on convergence to the US and Japanese real interest rates. Our sample covers the postliberalization period from 1985Q1 to 2006Q3. ${ }^{11}$ Because the timing of liberalization varies across countries, and because significant deregulation occurred as late as the early 1980s, we follow Baharumshah et al. (2005) and select 1985 as the beginning of our sample. ${ }^{12}$ All data except for those of Taiwan are from IMF's International Financial Statistics. Data for Taiwan are collected from the Taiwanese Monthly Bulletin of Statistics.

The nominal interest rate is the average of monthly effective money market rates. We choose money market rates rather than 90-day government bill rates because bond markets do not exist in some of the countries in our sample. Table 1 provides a description of the nominal interest rate data used in this paper. Inflation is calculated as the annualized growth rate of the consumer price index (CPI) from the last month of previous quarter to the last month of current quarter. Figure 1 illustrates the pattern of real interest rates for all fourteen countries used in this study. ${ }^{13}$

Because outliers may affect estimates of common factors, we test for outliers in each real interest differential using the method described in Perron and Rodriguez (2003). Estimated outliers are removed, and we apply PANIC to the cleansed interest differentials

\footnotetext{
${ }^{11}$ We use quarterly data because the consumer price index for Australia and New Zealand are not available at the monthly frequency. Using monthly data would increase the time series dimension of our panel at the cost of fewer cross-section units. However, PANIC tests have good power and are correctly sized when applied to panels with both large $N$ and $T$. Also, our data span is already reasonably long, and increasing frequency to increase the number of observations may only marginally improve the power of our tests (Shiller and Perron, 1985).

${ }^{12}$ Selecting 1985 as the first year of our sample also permits us to avoid the extreme observations in 1983-1984 for the Philippines. In December 1983 following civil unrest after the assassination of Benigno Aquino, the leading oppositionist to the former President Marcos, the Philippine inflation rate surged to nearly $93 \%$, and the nominal interest rate increased to $25 \%$.

${ }^{13}$ The Euro area CPI is available only after 1998. As a proxy for the CPI before 1998, we use a simple average of France and the U.K. CPIs from 1985Q1 to 1990Q4 and a simple average of Germany, France and the U.K. CPIs from 1991Q1 to 1997Q4. The quarterly data for Germany do not exist in the IFS prior to reunification.
} 
Table 1: Data Descriptions

\begin{tabular}{|c|c|c|}
\hline Country & Codes & Nominal Interest Rates \\
\hline United States & USA & Federal funds rate \\
\hline Japan & JPN & Call money rate \\
\hline Euro Area & EUA & $\begin{array}{l}\text { Three-month interbank rate (since 1994Q1), } \\
\text { Germany's call money rate (before 1994Q1) }\end{array}$ \\
\hline Canada & CAN & Overnight money market rate \\
\hline Hong Kong & HKG & Money market rate \\
\hline South Korea & KOR & Money market rate \\
\hline Singapore & SGP & Three-month interbank rate \\
\hline Taiwan & TWN & Interbank call loan rates \\
\hline Indonesia & IDN & Call money rate \\
\hline Malaysia & MYS & Interbank overnight money rate \\
\hline Philippines & PHL & Money market rate \\
\hline Thailand & THA & Money market rate \\
\hline Australia & AUS & Average rate on money market \\
\hline New Zealand & NZL & Money market rate \\
\hline
\end{tabular}

(Jolliffe, 2002, Ch. 10). See the Appendix for a description of the outlier test and results.

\section{$5 \quad$ Results}

\subsection{Individual and Other Panel Unit Root Tests}

We begin by testing for a unit root in the real interest rate differential, $D_{i, t}$, for each of the $i=1, \ldots, 11$ Pacific Basin economies. For univariate (i.e., country-specific) unit root tests, we use Ng and Perron's (2001) $M^{G L S}$ test and select the lag length for each test using their modified Akaike information criteria with a maximum lag length of four.

Based on the results, presented in Table 2, we reject the null of a unit root in the real interest differential for the Philippines for all base rates, for Indonesia, Malaysia, and Australia when either the US or Japanese real rates are used as the base rate, for 

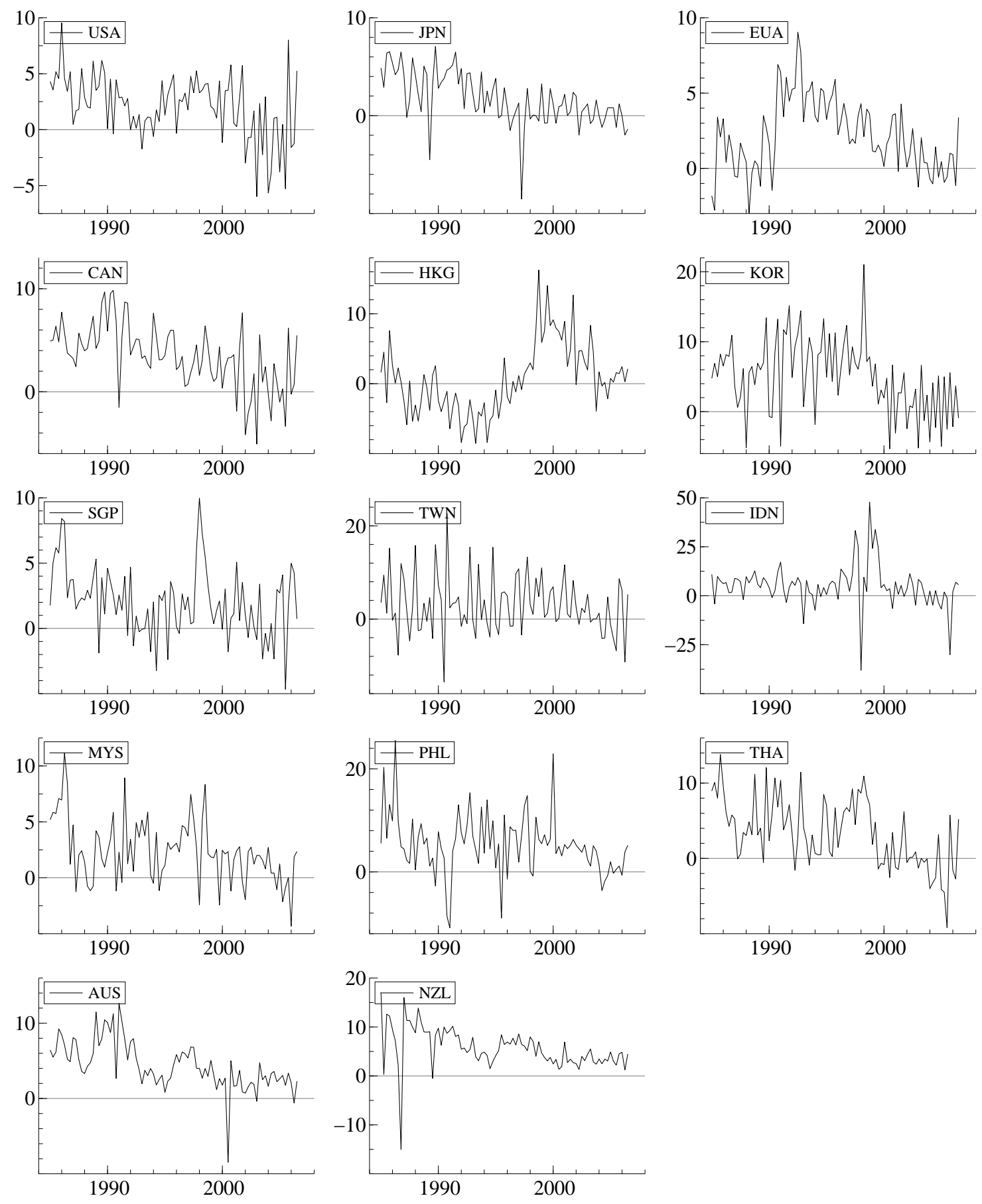

Figure 1: Real Interest Rates $\left(r_{i, t}\right)$, 1985Q1-2006Q3 
Canada when the US is the base country, and Thailand when Japan is the base country. Tests for a unit root in the real interest rate differential for each country provide little support for the RIP hypothesis, yet these results are unsurprising given the low power of univariate unit root tests in small samples.

Table 2: Univariate and Other Panel Unit Root Tests on Real Interest RATE DiffEREnTials

\begin{tabular}{lccc}
\hline \hline \multicolumn{3}{c}{ Base Rate } \\
& USA & JPN & EUA \\
\hline Univariate & Unit Root Test & & \\
CAN & $-1.935^{*}$ & -1.199 & -1.126 \\
HKG & -1.034 & -0.882 & -1.307 \\
KOR & -1.105 & -1.146 & -0.722 \\
SGP & -1.316 & -1.128 & -0.977 \\
TWN & -1.438 & -1.277 & -0.853 \\
IDN & $-2.767^{* * *}$ & $-2.352^{* *}$ & -1.607 \\
MYS & $-1.795^{*}$ & $-1.838^{*}$ & -0.485 \\
PHL & $-2.735^{* * *}$ & $-2.320^{* *}$ & $-2.041^{* *}$ \\
THA & -1.615 & $-1.854^{*}$ & -0.868 \\
AUS & $-1.696^{*}$ & $-2.087^{* *}$ & -0.882 \\
NZL & -0.394 & -1.087 & -0.085 \\
Panel Unit Root Test & & \\
IPS & $-3.498^{* * *}$ & $-2.850^{* * *}$ & $-2.809^{* * *}$ \\
CADF & $-2.870^{* * *}$ & $-3.102^{* * *}$ & $-2.770^{* * *}$
\end{tabular}

\section{Cross-Sectional Dependence Test on Residuals} from IPS Test

CD $15.877^{* * *} 15.775^{* * *} 12.357^{* * *}$
Notes: ${ }^{*},{ }^{* *},{ }^{* * *}$ denote statistical significance at $10 \%, 5 \%$ and $1 \%$, respectively.
The univariate test is the $\mathrm{MZ}_{t}^{G L S}$ test (Ng and Perron, 2001), IPS refers to Im,
Pesaran, and Shin (2003) panel unit root test, and CADF is the cross-sectionally
augmented ADF test proposed by Pesaran (2003). The CD test is the cross-section
dependence test proposed by Pesaran (2004). Lag lengths in the univariate tests
are chosen according to the modified Akaike information criteria (Ng and Perron,
2001) with the maximum lag of 4 . The same lags are used for the corresponding
cross-sectional units in the panel tests. See Table 1 for country codes.

The low power of univariate unit root tests is a primary motivation for the use of panel methods. Table 2 also reports results from the first-generation IPS panel tests 
and the second-generation CADF panel unit root tests. Both tests lead us to reject the unit root null at the $1 \%$ level regardless of the choice of base country. According to these results, there is strong evidence of RIP in the Pacific Basin, and we confirm the finding of Baharumshah et al. (2005) who used the IPS test to study RIP for a panel of ten East Asian countries. They rejected the hypothesis that real interest differentials are nonstationary. Yet, recall from the discussion in Section 3 that the first-generation IPS test is based on the restrictive assumption that cross-section units are independent. To test the validity of this assumption, we test for cross-sectional independence of the IPS test residuals using Pesaran's (2004) cross-section dependence (CD) test. ${ }^{14}$ Results, reported in Table 2, show that we can reject the null hypothesis of cross-sectional independence at the $1 \%$ significance level. Given this rejection, the IPS test is likely to be seriously oversized (O'Connell, 1998), and the IPS based rejections of the unit-root null are suspect.

While the second-generation CADF test does allow for cross-unit correlation, it models this correlation using a single common factor that is removed before testing for a unit root. The implicit assumption is that the common factor cannot be the source of nonstationarity, and the cross-section units cannot be cointegrated. We explore this assumption in more detail in our PANIC analysis below.

\footnotetext{
${ }^{14}$ The $\mathrm{CD}$ test statistic is $\mathrm{CD}=\sqrt{\frac{2 T}{N(N-1)}}\left(\sum_{i=1}^{N-1} \sum_{j=i+1}^{N} \widehat{\rho}_{j}\right)$ where $\widehat{\rho}_{j}$ is the estimated pairwise correlation coefficients of residuals. Pesaran shows that the CD statistic follows a limiting standard normal distribution, and that the test has better small sample properties than the Breusch and Pagan (1980) test. Results from Breusch-Pagan tests are similar from those of the CD test.
} 


\subsection{PANIC Test}

PANIC allows us to test for a unit root in the Pacific Basin real interest differentials without imposing the restrictive assumptions required for first-generation and early second-generation panel methods. The first task is to select $\widehat{r}$, the estimated number of common factors. We choose $\widehat{r}$ to minimize $I C_{p 2}(q)$, the information criterion in equation (10). Table 3 presents the $I C_{p 2}(q)$ value for $q=0, \ldots, 4$ when the base rate is the US, Japanese, or Euro rate. Regardless of which base rate is used, $q=1$ minimizes the

TABle 3: Information Criterion, $I C_{p 2}(q)$

\begin{tabular}{cccc}
\hline \hline Number of & \multicolumn{3}{c}{ Base Rate } \\
Factor $(q)$ & USA & JPN & EUA \\
\hline 0 & 0.000 & 0.000 & 0.001 \\
1 & $-0.230^{\dagger}$ & $-0.163^{\dagger}$ & $-0.068^{\dagger}$ \\
2 & -0.182 & -0.117 & -0.010 \\
3 & -0.159 & -0.086 & 0.038 \\
4 & -0.175 & -0.088 & 0.060 \\
\hline
\end{tabular}

Notes: ${ }^{\dagger}$ represents the lowest values for each base country. See equation (10) for the formula of $I C_{p 2}(q)$.

information criterion. Thus, we set $\widehat{r}=1$. Figure 2 plots the estimated common factors, and Table 4 shows the estimated factor loadings, $\lambda_{i}$, and the variances of common components, $\operatorname{Var}\left(\lambda_{i}^{\prime} f_{t}\right)$. Given that $d_{i, t}$ is standardized to have a unit variance, $\operatorname{Var}\left(\lambda_{i}^{\prime} f_{t}\right)$ can be interpreted as the variation of $d_{i, t}$ explained by variation in the common component. When the US real interest rate is the base rate, the results in the third column of Table 4 show that the factor common to all real rate differentials explains between $2 \%$ and $71 \%$ of the variation in the individual country differentials. The common factor explains less than $10 \%$ of the variation in the differentials for Korea and Taiwan and more than $50 \%$ 
of the variation for Hong Kong, Singapore, Malaysia, Australia and New Zealand. On average, the common factor accounts for $39 \%$ of the variation in the differences of the Pacific Basin economy real interest rates from the US real rate.

As shown in column five of Table 4, when the Japanese real rate is used as the base rate the common factor diminishes in importance somewhat. The common factor explains less than $10 \%$ of the variation in real interest differentials for Taiwan and Indonesia and more than $50 \%$ of the variation only for Canada. On average, the common factor accounts for $34 \%$ of the variation in the differences of the Pacific Basin economy real interest rates from the Japanese real rate. For the Euro area base rate, even less of the variation is due to the common factor. Little of the variation in Hong Kong, Taiwan and Indonesia is

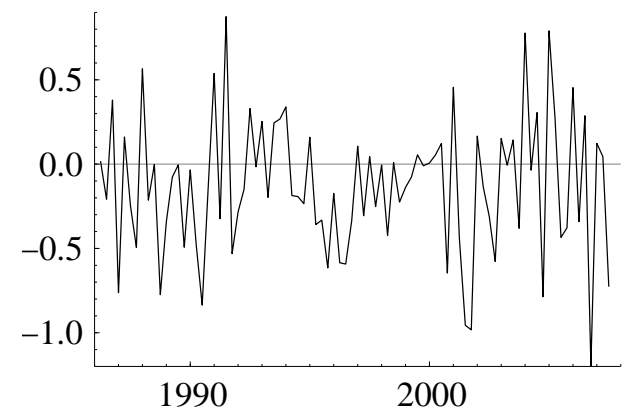

(a) USA as Base Country

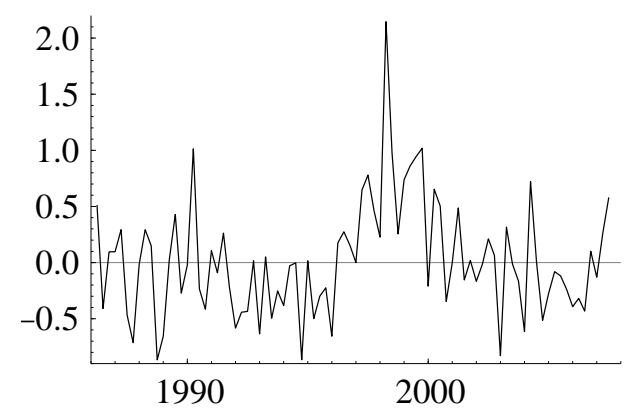

(b) Japan as Base Country

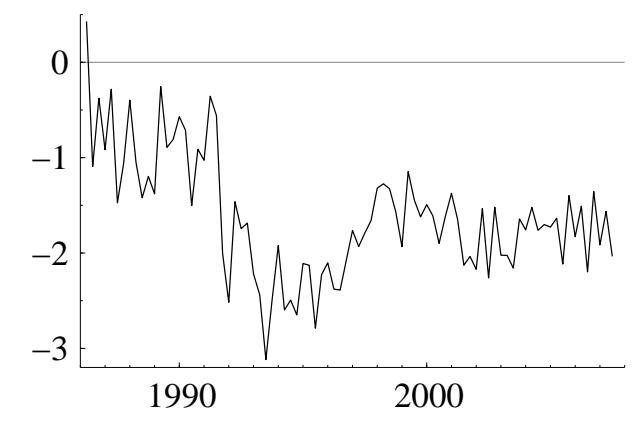

(c) Euro Area as Base Country

Figure 2: Common Factors $\left(F_{t}\right)$, Different Base Rates 
Table 4: Factor Analysis

\begin{tabular}{lcccccc}
\hline \hline & \multicolumn{6}{c}{ Base Rate } \\
& $\lambda_{i}$ & $\operatorname{VSA}\left(\lambda_{i}^{\prime} f_{t}\right)$ & $\lambda_{i}$ & $\operatorname{Var}\left(\lambda_{i}^{\prime} f_{t}\right)$ & $\lambda_{i}$ & $\mathrm{VUA}\left(\lambda_{i}^{\prime} f_{t}\right)$ \\
\hline CAN & 1.029 & 0.410 & 1.354 & 0.623 & 1.237 & 0.419 \\
HKG & 1.226 & 0.582 & 1.183 & 0.476 & 0.480 & 0.063 \\
KOR & 0.209 & 0.017 & 0.972 & 0.322 & 1.064 & 0.310 \\
SGP & 1.186 & 0.545 & 1.034 & 0.364 & 1.096 & 0.329 \\
TWN & 0.363 & 0.051 & 0.234 & 0.019 & 0.559 & 0.085 \\
IDN & 0.605 & 0.142 & 0.476 & 0.077 & -0.338 & 0.031 \\
MYS & 1.349 & 0.706 & 1.139 & 0.442 & 1.014 & 0.281 \\
PHL & 0.886 & 0.305 & 0.656 & 0.147 & 0.970 & 0.257 \\
THA & 0.852 & 0.281 & 1.060 & 0.382 & 1.228 & 0.413 \\
AUS & 1.274 & 0.630 & 1.192 & 0.484 & 1.260 & 0.434 \\
NZL & 1.240 & 0.596 & 1.096 & 0.409 & 1.188 & 0.386 \\
\hline
\end{tabular}

Notes: $\lambda_{i}$ is the factor loading, and $\operatorname{Var}\left(\lambda_{i}^{\prime} f_{t}\right)$ is the variance of common component. See Table 1 for country codes.

explained by the common factor, and no real interest differential has more than $50 \%$ of its variation explained by the common factor. On average, the common factor accounts for only $27 \%$ of variation in the data.

Table 5 presents results from unit root tests on both the common factors and the idiosyncratic components. When the US rate is used as the base rate, we conclude that the common factor is stationary. The DF-GLS test statistic is -2.861 , and we reject the null hypothesis of a unit root at 5\% significance level. In contrast, when the Japanese and Euro rate are used as the base rate, we can not reject the null of a unit root in the common factor. The DF-GLS statistics are -1.299 and -0.160 respectively, both tests are insignificant at even the $10 \%$ level.

This result is important because failure to reject the null of a unit root in the common factor implies that the CADF test is likely to produce misleading conclusions. 
Table 5: Unit Root Tests on Common and Idiosyncratic components of Real Interest Rate Differentials

\begin{tabular}{llll}
\hline \hline & & Base Rate \\
& USA & JPN & EUA \\
\hline Common Factors & & \\
Factor1 & $-2.861^{* *}$ & -1.299 & -0.160 \\
Idiosyncratic Components & & \\
Univariate Tests & & \\
CAN & $-2.253^{* *}$ & -1.597 & $-2.012^{* *}$ \\
HKG & -1.073 & -1.041 & -1.221 \\
KOR & $-2.057^{* *}$ & $-1.684^{*}$ & -0.805 \\
SGP & $-3.257^{* * *}$ & $-2.750^{* * *}$ & $-2.458^{* *}$ \\
TWN & $-9.855^{* * *}$ & $-1.829^{*}$ & $-3.021^{* * *}$ \\
IDN & -1.306 & -1.554 & $-2.488^{* *}$ \\
MYS & $-3.120^{* * *}$ & $-3.298^{* * *}$ & $-2.954^{* * *}$ \\
PHL & -1.141 & -1.317 & $-2.284^{* *}$ \\
THA & -1.372 & $-1.762^{*}$ & $-2.838^{* * *}$ \\
AUS & $-1.690^{*}$ & $-2.004^{* *}$ & $-2.487^{* *}$ \\
NZL & -1.036 & $-3.992^{* * *}$ & -1.568 \\
Pooled Test (PMSB) & $-2.741^{* * *}$ & $-2.696^{* * *}$ & $-2.592^{* * *}$ \\
\hline Notes: ${ }^{* * *},{ }^{* * *}$ denote statistical significance at $10 \%, 5 \%$ and $1 \%$, respectively. The \\
unit root test on the common factor and the individual idiosyncratic components is \\
the DF-GLS (Elliott, Rothenberg, and Stock, 1996). The pooled test is the PMSB \\
test proposed by Bai and Ng (2007). See Table 1 for country codes. \\
\end{tabular}

Recall that the CADF test filters out the common factor before testing for a unit root. By removing a potential source of nonstationarity - the common factor - the CADF test may lead to a rejection of the unit root null when the real interest rate differentials are in fact nonstationary, and RIP does not hold.

We now turn our attention to tests for a unit root in the idiosyncratic components, $\widehat{E}_{i, t}$. Table 5 reports results from both univariate DF-GLS unit root tests as well as the PMSB test for a unit root in the pooled idiosyncratic components. ${ }^{15}$ When the US is

\footnotetext{
${ }^{15}$ For the univariate tests, we employ the DF-GLS here instead of the ADF test suggested by Bai and $\mathrm{Ng}$ (2004) following Gutierrez's (2006) suggestion.
} 
the base country, we reject the null of a unit root in the idiosyncratic components for six of the eleven Pacific Basin economies at the $10 \%$ significance level or lower. We can not reject a unit root for Hong Kong, Indonesia, the Philippines, Thailand and New Zealand. Results using the Japanese rate as the base rate are similar. With the Euro rate as the base rate, we can reject the null at the $10 \%$ significance level for all economies except Hong Kong, Korea and New Zealand. Again, because of the increased power of the panel unit root test, we prefer the PMSB test over the univariate tests. The PMSB statistics are between -2.59 and -2.75 for all base rates, and we reject the null hypothesis that the panel of idiosyncratic factors are $I(1)$ at the $1 \%$ significance level.

The panel of real interest differentials is $I(0)$ if and only if we can reject the unit root hypothesis for both the common and idiosyncratic components. While we reject the null of a unit root in the idiosyncratic components regardless of our choice of base country, and we reject the null of a unit root in the common factor when the U.S. is the base country, we can not reject the null of a unit root in the common factor when either Japan or the Euro area are used as the base country.

We conclude that RIP holds between Pacific Basin economies and the U.S. Our results overturn the findings of Baharumshah et al. (2005). Real interest rates in Pacific Basin economies do not converge to either the Japanese real interest rate or to the Euro real rate. When these two rates are used as the base rate, we find a single common factor that is nonstationary. Early panel unit root tests are unable to detect this nonstationarity because the common factor accounts for a small fraction of the variation in the real interest rate differentials. 


\section{Conclusion}

While there appears to be a growing consensus that Pacific Basin financial markets and goods market are well integrated, there is less agreement on the equality of real interest rates across countries. We exploit advances in panel data econometrics to test whether real interest parity holds in the Pacific Basin region and to determine which economy, the US, Japan or even the Euro Area, exerts the greatest influence in the region. We test for a unit root in the difference between either the US, Japanese or Euro area real interest rate and the real interest rates from a panel of eleven Pacific Basin economies. Unlike extant studies which test for RIP using panel data, we use Bai and Ng's (2004) PANIC test which allows for a very general model of cross-section dependence, including the possibility of cross-unit cointegration. Because ignoring the possibility of cross-unit cointegration can lead to severe size distortions and to an overrejection of the null hypothesis of a unit root, early studies using panel methods based on the assumption of no cross-unit cointegration or even cross-sectional independence should be interpreted with caution (Banerjee, Marcellino, and Osbat, 2005). In fact, we confirm the findings of Baharumshah et al. (2005) using the first generation IPS test, and demonstrate that cross-unit cointegration is the likely cause of their results. We find that RIP holds in the Pacific region. Real interest rates do converge, and they converge to the US rate. In contrast to Baharumshah et al. (2005), we find no support for the hypothesis that Pacific Basin real interest rates converge to the Japanese rate. We reject the convergence of Pacific region real rates to the Japanese rate even at the $10 \%$ significance level. Finally, we find no support for the hypothesis that real interest 
rates in the Pacific region converge to the Euro Area rate. 


\section{APPENDIX}

We test for additive outliers using the method described in Perron and Rodriguez (2003). For each real interest differential, $D_{i t}$, we estimate

$$
\Delta D_{i t}=\gamma \Delta I\left(T_{0}\right)_{t}+v_{t} \quad t=2, \ldots, T
$$

where $I\left(T_{0}\right)_{t}=1$ if $t=T_{0}$ and 0 otherwise, and $T_{0} \in(2, \ldots, T-1)$. The $t$-statistic on $\widehat{\gamma}$ for a given $T_{0}$ is given by

$$
t_{\widehat{\gamma}}\left(T_{0}\right)=\frac{\widehat{\gamma}}{\sqrt{\left(\frac{\widehat{R}_{v}(0)-\widehat{R}_{v}(1)}{2}\right)}}
$$

where $\widehat{R}_{v}(j)=T^{-1} \sum_{t=1}^{T-j} \widehat{v}_{t} \widehat{v}_{t+j}$. The null hypothesis of an outlier at $T_{0}$ is tested using the sup-t statistic $\tau_{d}=\sup _{T_{0}}\left|t_{\widehat{\gamma}}\left(T_{0}\right)\right|$. The critical value at the $5 \%$ significance level is 3.65 for $T=100$. Once an outlier is detected, say at $T_{0}=\tau$, we drop the observation on $D_{i \tau}$, and repeat the procedure to detect another outlier. All outliers are detected when no sup-t statistics are significant. Once all outliers are detected we fit a model similar to (A-1) with dummies for all outliers included on the right-hand side. Let $\widehat{v}_{t}$ be the residuals from such model. The data with outliers removed is given by

$$
D_{i t}=D_{i 1}+\sum_{j=2}^{t} \widehat{v}_{j} \quad t=2, \ldots, T .
$$

Table A-1 present the results of outlier tests on real interest differentials for all eleven pacific basin economies and each base rate. ${ }^{16}$ We find outliers for Indonesia in 1998Q1, 1998Q4 and 2005Q4 regardless of the choice of the base rate. The first two outliers correspond to the Asian financial crisis. In 1998Q1, inflation in Indonesia spiked

\footnotetext{
${ }^{16}$ Only results where an outlier is detected are reported.
} 
to $96 \%$, and in 2005Q4 when the Indonesian government reduced its fuel price subsidy, inflation jumped to $38 \%$. In New Zealand and Australia, we find outliers around the introduction of Goods and Services Taxes (GST). The GST was first introduced in New Zealand on October 1, 1986 at 10\%. It was later increased to $12.5 \%$ on June 30, 1989. Australia adopted the GST on July 1, 2000. The introduction of a GST (or a large rate change) is usually associated with a surge in inflation, and we detect outliers in those periods. We also find outliers for Hong Kong early in the sample (1985Q3) and after the 9/11 terrorist attack on the US (but only when EUA is the base). We also find outliers in 1990Q4 in Taiwan when Japan is the base country and in Australia when Japan or EUA is the base country.

TABle A-1: OutLiers

\begin{tabular}{|c|c|c|c|c|c|c|}
\hline & \multicolumn{6}{|c|}{ Base Rate } \\
\hline & \multicolumn{2}{|c|}{ USA } & \multicolumn{2}{|c|}{ JPN } & \multicolumn{2}{|c|}{ EUA } \\
\hline & Period & $\tau_{d}$ & Period & $\tau_{d}$ & Period & $\tau_{d}$ \\
\hline \multirow[t]{2}{*}{$\mathrm{HKG}$} & & & & & 1985Q3 & 3.933 \\
\hline & & & & & $2001 Q 4$ & 3.917 \\
\hline TWN & & & 1990Q4 & 3.828 & & \\
\hline \multirow[t]{3}{*}{ IDN } & 1998Q1 & 5.307 & 1998Q1 & 5.712 & 1998Q1 & 6.537 \\
\hline & 1998Q4 & 4.570 & 1998Q4 & 4.677 & 1998Q4 & 4.565 \\
\hline & $2005 \mathrm{Q} 4$ & 4.798 & $2005 \mathrm{Q} 4$ & 4.786 & $2005 \mathrm{Q} 4$ & 5.058 \\
\hline \multirow[t]{3}{*}{ AUS } & & & 1990Q4 & 3.765 & 1990Q4 & 5.083 \\
\hline & & & 1997Q2 & 4.051 & 2000Q3 & 6.526 \\
\hline & & & $2000 \mathrm{Q} 3$ & 4.535 & & \\
\hline \multirow[t]{3}{*}{ NZL } & 1986Q4 & 6.009 & 1985Q2 & 4.637 & 1985Q2 & 4.786 \\
\hline & & & 1986Q4 & 7.355 & 1986Q4 & 7.553 \\
\hline & & & 1989Q2 & 4.321 & 1989Q3 & 4.430 \\
\hline
\end{tabular}




\section{References}

Aggarwal, R., Montanes, A., Ponz, M., 2000. Evidence of Long-Run Purchasing Power Parity: Analysis of Real Asian Exchange Rates in Terms of the Japanese Yen. Japan and the World Economy 12, 351-361.

Aggarwal, R., Mougoue, M., 1996. Cointegration among Asian Currencies: Evidence of the Increasing Influence of the Japanese Yen. Japan and the World Economy 8, 291-308.

Azali, M., Habibullah, M., Baharumshah, A., 2001. Does PPP Hold between Asian and Japanese Economies? Evidence Using Panel Unit Root and Panel Cointegration. Japan and the World Economy 13, 35-50.

Baharumshah, A. Z., Ariff, M., 1997. Purchasing Power Parity in South East Asian Countries Economies: A Cointegration Approach. Asian Economic Journal 11 (2), $141-153$.

Baharumshah, A. Z., Haw, C. T., Fountas, S., 2005. A Panel Study on Real Interest Rate Parity in East Asian Countries: Pre- and Post-Liberalization Era. Global Finance Journal 16, 69-85.

Baharumshah, A. Z., Keat, G. W., 2005. Financial Integration of East Asia: Is There a Yen Block? In: Baharumshah, A. Z. (Ed.), Open Economy Macroeconomics in East Asia. Ashgate, Ch. 8, pp. 147-168.

Bai, J., Carrion-i-Silvestre, J. L., 2005. Testing Panel Cointegration with Unobservable Dynamic Common Factors, mimeo.

Bai, J., Ng, S., 2002. Determining the Number of Factors in Approximate Factor Models. Econometrica 70 (1), 191-221.

Bai, J., Ng, S., 2004. A PANIC Attack on Unit Roots and Cointegration. Econometrica 72 (4), 1127-1177.

Bai, J., Ng, S., 2007. Panel Unit Root Tests with Cross-Section Dependence: A Further Investigation, mimeo.

Banerjee, A., Marcellino, M., Osbat, C., 2005. Testing for PPP: Should We Use Panel Methods? Empirical Economics 30 (1), 77-91.

Breitung, J., Pesaran, M. H., 2008. Unit Roots and Cointegration in Panels. In: Matyas, L., Sevestre, P. (Eds.), The Econometrics of Panel Data, 3rd Edition. Vol. 46 of Advanced Studies in Theoretical and Applied Econometrics. Springer, Ch. 9, pp. 279-322.

Breusch, T., Pagan, A., 1980. The Lagrange Multiplier Test and Its Applications to Model Specification in Econometrics. Review of Economic Studies 47, 239-254. 
Chinn, M. D., Frankel, J. A., 1995. Who Drives Real Interest Rates around the Pacific Rim: the USA or Japan? Journal of International Money and Finance 14 (6), 801-821.

Cooray, A., 2003. The Fisher Effect: A Survey. Singapore Economic Review 48 (2), $135-150$.

Cowen, D., Salgodo, R., Shah, H., Teo, L., Zanello, A., 2006. Financial Integration in Asia: Recent Developments and Next Steps, IMF working paper WP/06/196.

Cumby, R. E., Mishkin, F. S., 1986. The International Linkage of Real Interest Rates: The European-US Connection. Journal of International Money and Finance 5, 5-23.

Cumby, R. E., Obstfeld, M., 1984. International Interest Rate and Price Level Linkages under Flexible Exchange Rates: A Review of Recent Evidence. In: Bilson, J. F., Marston, R. C. (Eds.), Exchange Rate Theory and Practice. University of Chicago Press, Chicago, Ch. 3, pp. 121-151.

Das, D. K., 2005. Asian Economy and Finance. Springer, New York.

de Brouwer, G., 2002. Integrating Financial Markets in East Asia. In: Lee, K. T. (Ed.), Globalization and the Asia Pacific Economy. Routledge, Ch. 10, pp. 199-225.

Dickey, D. A., Fuller, W. A., 1979. Distribution of the Estimators for Autoregressive Time Series With a Unit Root. Journal of the American Statistical Association 74, 427-31.

Edison, H., Pauls, B., 1993. A Re-Examination of the Relationship Between Real Exchange Rates and Real Interest Rates: 1974-1990. Journal of Monetary Economics 31 (2), 165-187.

Elliott, G., Rothenberg, T. J., Stock, J. H., 1996. Efficient Tests for an Autoregressive Unit Root. Econometrica 64 (4), 813-836.

Ferreira, A. L., Leon-Ledesma, M. A., 2007. Does the Real Interest Parity Hypothesis Hold? Evidence for Developed and Emerging Markets. Journal of International Money and Finance 26, 364-382.

Fountas, S., Wu, J., 1999. Testing for Real Interest Rate Convergence in European Countries. Scottish Journal of Political Economy 46 (2), 158-174.

Gengenbach, C., Palm, F. C., Urbain, J.-P., 2005. Panel Unit Root Tests in the Presence of Cross-Sectional Dependencies: Comparison and Implications for Modelling, mimeo.

Glick, R., 1987. Interest Rate Linkage in the Pacific Basin. San Francisco Federal Reserve Bank Economic Review, 31-42.

Glick, R., Hutchison, M. M., 1990. Financial Liberalization in the Pacific Basin: Implications for Real Interest Rate Linkage. Journal of the Japanese and International Economies 4, 36-48. 
Goodwin, B. K., Grennes, T. J., 1994. Real Interest Rate Equalization and the Integration of International Financial Markets. Journal of International Money and Finance 13 (1), $107-124$.

Gutierrez, L., 2006. Panel Unit-Root Tests for Cross-Sectionally Correlated Panels: A Monte Carlo Comparison. Oxford Bulletin of Economics and Statistics 68 (4), 519-540.

Holmes, M. J., 2002. Does Long-Run Real Interest Parity Hold among EU Countries? Some New Panel Data Evidence. Quarterly Review of Economics and Finance 42, $733-746$.

Im, K. S., Pesaran, M. H., Shin, Y., 2003. Testing for Unit Roots in Heterogenous Panels. Journal of Econometrics 115, 53-74.

Jolliffe, I. T., 2002. Principal Component Analysis, 2nd Edition. Springer, New York.

Jorion, P., 1996. Does Real Interest Parity Hold at Longer Maturities? Journal of International Economics 40, 105-126.

Levin, A., Lin, C.-F., 1993. Unit Root Tests in Panel Data: Asymptotic and FiniteSample Properties, University of California San Diego.

MacDonald, R., Nagayasu, J., 2000. The Long-Run Relationship Between Real Exchange Rates and Real Interest Rates Differentials: A Panel Study, IMF Staff Papers 47(1).

Maddala, G., Wu, S., 1999. A Comparative Study of Unit Root Tests with Panel Data and a New Simple Test. Oxford Bulletin of Economics and Statistics 61, 631-652.

Meese, R., Rogoff, K., 1988. Was It Real? the Exchange Rate-Interest Rate Differential Relation over the Modern Floating-Rate Period. Journal of Finance 43 (4), 933-948.

Mishkin, F. S., 1984. Are Real Interest Rates Equal Across Countries? An Empirical Investigation of International Parity Conditions. Journal of Finance 39 (5), 1345-1357.

Moon, H. R., Perron, B., 2004. Testing for a Unit Root in Panels with Dynamic Factors. Journal of Econometrics 122, 81-126.

Ng, S., Perron, P., 2001. Lag Length Selection and the Construction of Unit Root Tests with Good Size and Power. Econometrica 69 (6), 1519-1554.

Obstfeld, M., Taylor, A. M., 2002. Globalization and Capital Markets, NBER working paper 8846 .

O’Connell, P. G., 1998. The Overvaluation of Purchasing Power Parity. Journal of International Economics 44, 1-19.

Perron, P., Rodriguez, G., 2003. Searching for Additive Outliers in Nonstationary Time Series. Journal of Time Series Analysis 24 (2), 193-220. 
Pesaran, M. H., 1987. The Limits to Rational Expectations. Blackwell Publisher, New York.

Pesaran, M. H., 2003. A Simple Panel Unit Root Test in the Presence of Cross Section Dependence, Working Papers in Economic 0346, University of Cambridge.

Pesaran, M. H., 2004. General Diagnostic Tests for Cross Section Dependence in Panels, mimeo.

Pesaran, M. H., 2007. A simple Panel Unit Root Test in the Presence of Cross Section Dependence. Journal of Applied Econometrics 22 (2), 265-312.

Phylaktis, K., 1999. Capital Market Integration in the Pacific Basin Region: An Impulse Response Analysis. Journal of International Money and Finance 18, 267-287.

Roll, R., 1979. Violations of Purchasing Power Parity and their Implications for Efficient International Commodity Markets. In: Sarnat, M., Szego, G. P. (Eds.), International Finance and Trade. Cambridge, MA: Ballinger, pp. 133-176.

Sekioua, S. H., 2008. Real Interest Parity (RIP) over the 20th Century: New Evidence Based on Confidence Intervals for the Largest Root and the Half-Life. Journal of International Money and Finance 27, 76-101.

Shiller, R. J., Perron, P., 1985. Testing the Random Walk Hypothesis: Power versus Frequency of Observation. Economics Letter 18, 381-386.

Singh, M., Banerjee, A., 2006. Testing Real Interest Parity in Emerging Markets, IMF Working Paper WP/06/249.

Stock, J. H., 1999. A Class of Tests for Integration and Cointegration. In: Engle, R. F., White, H. (Eds.), Cointegration, Causality and Forecasting. A Festchrift in Honour of Clive W. F. Granger. Oxford University Press, pp. 137-167.

Tse, Y., Ng, L., 1997. The Cointegration of Asian Currencies Revisited. Journal of the World Economy 9, 109-114.

Wu, J.-L., Chen, S.-L., 1998. A Re-Examination of Real Interest Rate Parity. Canadian Journal of Economics 31 (4), 837-851.

Wu, J.-L., Fountas, S., 2000. Real Interest Rate Parity Under Regime Shifts and Implication for Monetary Policy. The Manchester School 68 (6), 685-700.

Yamada, H., 2002. Real Interest Rate Equalization: Some Empirical Evidence from the Three Major World Financial Markets. Applied Economics 34, 2069-2073. 